\title{
PENERAPAN METODE FILTRASI, ADSORPSI DAN REVERSE OSMOSIS UNTUK PENGOLAHAN AIR SUNGAI MENJADI AIR SIAP MINUM
}

\section{IMPLEMENTATION OF FILTRATION, ADSORPTION AND REVERSE OSMOSIS METHODS FOR PROCESSING RIVER WATER INTO POTABLE WATER}

\author{
Nurul Ismillayli $^{1}$, Laili Mardiana $^{2}$, Rina Kurnianingsih ${ }^{3}$, Dhony Hermanto ${ }^{1}$, Fahrurazi ${ }^{1}$ \\ ${ }^{1}$ Program Studi Kimia, FMIPA, Universitas Mataram. Jalan Majapahit No 62 Mataram, 83125, Indonesia \\ ${ }^{2}$ Program Studi Fisika, FMIPA, Universitas Mataram, Jalan Majapahit No 62 Mataram, 83125, Indonesia \\ ${ }^{3}$ Program Studi Biologi, FMIPA, Universitas Mataram, Jalan Majapahit No 62 Mataram, 83125, Indonesia \\ Email:nurul.ismillayli@unram.ac.id
}

Diterima: 10 Februari 2018. Disetujui: 22 Maret 2018. Dipublikasikan: 31 Maret 2018

\begin{abstract}
Abstrak: Penerapan teknologi tepat guna tentang proses pengolahan air siap minum dengan menggunakan metode filtrasi, adsorpsi dan reverse osmosis telah dilakukan. Rancangan alat pengelolaan air siap minum menggunakan kombinasi filtrasi-adsorpsi meliputi saringan pasir lambat (terdiri dari pasir silika, arang aktif, ijuk, kapas, dan kerikil) membran selulosa, granula karbon, karbon aktif, membran RO (reverse osmosis), dan lampu ultraviolet untuk desinfikasi. Penentuan beberapa parameter fisik (bau, warna), kimia ( $\mathrm{pH}, \mathrm{Fe}$, nitrit, amonia, $\left.\mathrm{BOD}_{5}, \mathrm{COD}, \mathrm{DO}\right)$ dan biologi (bakteri E-coli) dari sumber air (irigasi) dan air hasil pemurnian dilakukan di Laboratorium Kimia Universitas Mataram dan Balai Laboratorium Kesehatan Pengujian dan Kalibrasi Provinsi NTB. Air siap minum yang dihasilkan memiliki kualitas sesuai dengan baku mutu air minum Peraturan Menteri Kesehatan Nomor 492/Menkes/Per/IV/2010 Tanggal 19 April 2010. Hasil uji organoleptik menunjukkan bahwa masyarakat menyukai air hasil pengolahan dan merespon positif terhadap alih teknologi pengolahan air. Pembangunan sentra pengelohan air siap minum diharapkan menjadi edukasi bagi masyarakat mengenai perilaku hidup bersih dan sehat.
\end{abstract}

Kata kunci: filtrasi, adsorpsi, reverse osmosis, air sungai, air siap minum

\begin{abstract}
Implementation of appropriate technology on the process of potable water using filtration, adsorption and reverse osmosis methods has been done. Its design used a combination of filtration-adsorption includes slow sand filters (consisting of silica sand, activated charcoal, palm fiber, cotton, and gravel) cellulosic membranes, carbon granules, activated carbon, RO (reverse osmosis) membranes, and ultraviolet for disinfection. Determination of several physical (odor, color), chemical ( $\mathrm{pH}$, Fe, nitrite, ammonia, $\mathrm{BOD}_{5}, \mathrm{COD}_{\text {, }}$ DO) and biological parameters (E-coli) of purified water were conducted at Chemical Laboratory of Mataram University and Health Laboratory Testing and Calibration Center of West Nusa Tenggara Province. The potable water produced has quality according to the quality standard of drinking water Regulation of the Minister of Health No. 492/Menkes/Per/IV/2010 Date April 19, 2010. The organoleptic test showed that the community responds positively to the knowledge transfer of water treatment technology. The construction of potable water center is expected to educate the public about clean and healthy living behavior.
\end{abstract}

Keywords: filtration, adsorption, reverse osmosis, river water, potable water

\section{PENDAHULUAN}

Sebagai jantung dari Kabupaten Kabupaten Lombok Tengah, Kecamatan Praya terletak di bagian Tengah wilayah Kabupaten Lombok Tengah dengan luas wilayah mencapai 6.126 ha atau sekitar 5,07 \% dari luas Kabupaten Lombok Tengah. Secara administrasi wilayah ini terbagi menjadi 15 desa/kelurahan, salah satunya adalah Desa Jago yang memiliki luas wilayah paling tinggi dengan luas $913 \mathrm{Ha}$ atau sekitar 15 persen dari luas Kabupaten Lombok Tengah. Kondisi sosial ekonomi penduduk desa jago hampir sama dengan kondisi masyarakat Lombok Tengah secara umum. Dengan struktur tanah yang tergolong cukup subur menyebabkan aktivitas kegiatan ekonomi masyarakat di Desa Jago masih dominan pada kegiatan di sektor pertanian. Hal ini didukung dengan tersedianya lahan sawah di Desa Jago dengan luasan tertinggi di Lombok Tengah sekitar 751 ha [1].

Masyarakat Desa Jago secara umum menggunakan sumur sebagai sumber air untuk memenuh kebutuhan hidupnya terutama untuk kebutuhan air minum. Sumber air ini merupakan sumber air minum tak terlindungi yang memiliki peluang tercemar virus dan bakteri yang dapat menyebabkan beberapa penyakit seperti diare, kolera, tifus, infeksi E-coli, hepatitis A, dan polio, mengingat pola hidup masyarakat yang 
mengalirkan air limbah domestik ke sungai baik langsung maupun tidak langsung. Selain itu dengan tingginya aktivitas sektor pertanian yang menggunakan pupuk dan pestisida, dimungkinkan bahan kimia dan hasil peruraianya akibat proses leaching terbawa aliran air kemudian meresap ke dalam tanah dan masuk ke dalam sumber air tak terlindungi [2]. Hal ini diindikasikan dengan hasil pengukuran kadar nitrit dan ammonia di beberapa sungai yang mengaliri Desa ini melebihi baku mutu air kelas I sebagai bahan baku air minum [3]. Kontaminan jenis ini tidak dapat diatasi hanya dengan mendidihkan bahan baku air minum seperti halnya kontaminan bakteri atau virus.

Sistem pengolahan air minum yang mampu meningkatkan kualitas air minum meliputi aspek fisik, kimia dan biologi sehingga sumber daya air lokal menjadi aman dan layak dikonsumsi masyarakat sangat dibutuhkan. Pengolahan air ini dapat menjamin kebutuhan dasar masyarakat akan air bersih dapat terpenuhi. Proses pemilihan teknologi pengolahan air siap minum yang aman dan layak harus disesuaikan dengan kondisi sosial ekonomi masyarakat Desa Jago, yaitu tingginya angka kemiskinan dan rendahnya tingkat pendidikan [4,5]. Solusi yang diterapkan adalah pembangunan unit pengolahan sumber daya air tersedia menjadi air layak minum [6]. Selain itu masyarakat juga diedukasi untuk memiliki pola hidup bersih dan sehat melalui berperan aktif menjaga sumber daya air tersedia dan menggunakan air bersih untuk pemenuhan kebutuhan sehari-hari.

\section{METODE KEGIATAN}

Kegiatan diawali dengan survei terhadap kondisi lingkungan Desa Jago terutama tentang sumber daya air. Selanjutnya dilakukan pembangunan sentra pengolahan air siap minum pada salah satu lahan milik kelompok tani dengan mengutamakan letak strategisnya (baik dari kedekatan sumber air maupun dengan pemukiman anggota kelompok tani yang lain). Rancangan alat pengelolahan air siap minum menggunakan kombinasi filtrasi adsorpsi oleh saringan pasir lambat (terdiri dari pasir silika, arang aktif, sabut kelapa, kapas, dan kerikil) membrane selulosa, granula karbon, karbon aktif, membrane RO (reverse osmosis), dan penyinaran lampu ultraviolet untuk air siap minum. Air hasil pengolahan diuji parameter fisik (bau, warna), kimia ( $\mathrm{pH}, \mathrm{Fe}$, nitrit, amonia, BOD5, COD, DO) dan biologi (bakteri E-coli). Uji organoleptik dan respon pengguna air dilakukan melalui pengisian kuisoner tentang kualitas air, harga air dan kebersihan tempat pengolahan air dan karyawan setelah konsumen menggunakan air selama satu minggu. Sosialisasi kepada masyarakat desa jago juga dilakukan sebagai sarana alih teknologi tentang pengelahan air siap minum dan sebagai edukasi bagi masyarakat mengenai perilaku hidup bersih dan sehat serta pemanfaatan air secara bijak dan efektif.

\section{HASIL DAN PEMBAHASAN}

Sumber air sebagai bahan baku adalah air sungai yang merupakan saluran irigasi Desa Jago. Sentra alat pengolahan air dibangun di halaman rumah salah satu warga Desa Jago yang memiliki akses terhadap saluran irigasi sebagai sumber air [6] dengan skema seperti Gambar 1 berikut

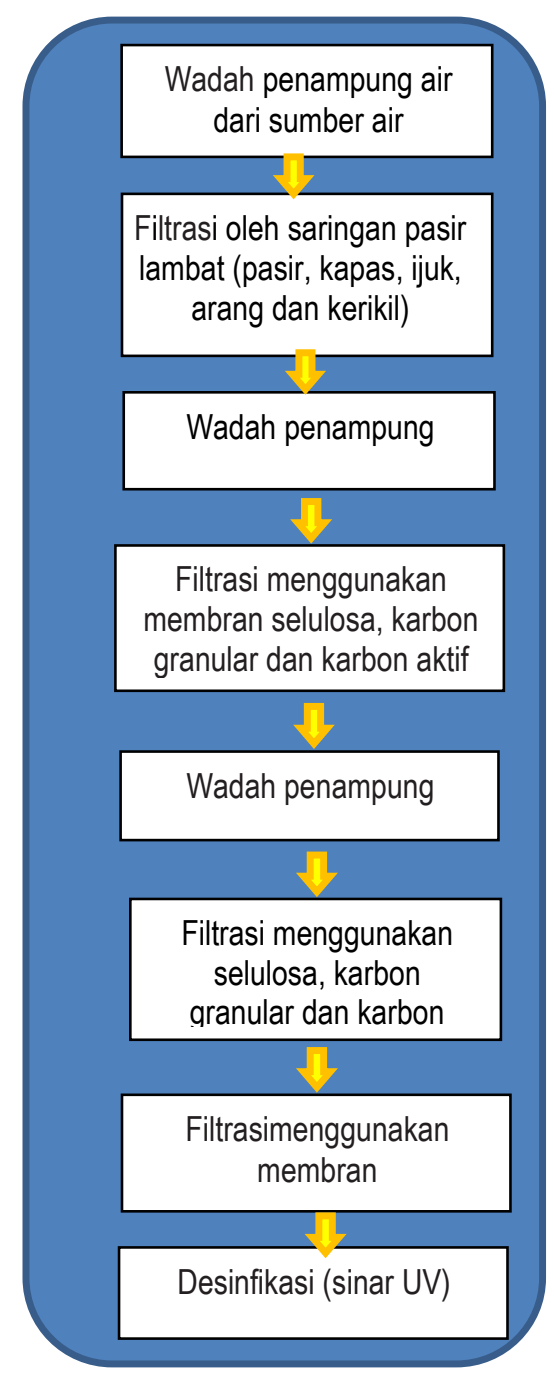

Gambar 1 Skema alat pengolahan air

Pembangunan dan pengujian unit pengolahan air dilakukan kurang lebih selama seminggu. Air hasil pengolahan diujikan beberapa parameter kimia (Fe, nitrit, amonia, $\mathrm{BOD}_{5}, \mathrm{COD}$, DO) dan biologi (bakteri E-coli). Hasil uji menunjukkan bahwa air hasil pengolahan merupakan air layak minum, seperti tercantum pada 
Tabel 1. Kondisi air sebelum pengolahan dan setelah pengolahan terdapat pada Gambar 2

Tabel 1. Hasil uji air produk pengolahan

\begin{tabular}{lcc}
\hline Parameter & $\begin{array}{c}\text { Kadar } \\
\text { sebenarnya }\end{array}$ & $\begin{array}{c}\text { Kadar maksimum } \\
\text { yang } \\
\text { diperbolehkan }\end{array}$ \\
\hline Fisika
\end{tabular}

Fisika

\begin{tabular}{lcc} 
a. Warna & 0 TCU & 15 TCU \\
b. Bau & Tidak berbau & Tidak berbau \\
c. Rasa & Tidak berasa & Tidak berasa \\
d. Suhu & $25^{\circ} \mathrm{C}$ & Suhu udara $\pm 3^{\circ}$ \\
\hline
\end{tabular}

Kimia

\begin{tabular}{lcc} 
a. Fe & 0 & $0,3 \mathrm{mg} / 1$ \\
b. $\mathrm{pH}$ & 6,76 & $6,5-8,5$ \\
c. nitrit & 0 & $1 \mathrm{mg} / 1$ \\
d. amonia & 0 & $1,5 \mathrm{mg} / 1$ \\
e. $\mathrm{DO}$ & 5 & \\
f. $\mathrm{BOD} 5$ & $1 \mathrm{mg} / \mathrm{l}$ & $6 \mathrm{mg} / \mathrm{l}$ \\
g. COD & $0 \mathrm{~m} / 1$ & $12 \mathrm{mg} / 1$ \\
\hline
\end{tabular}

Biologi

E Coli

0

0

Keterangan:

*Berdasarkan pengukuran Balai Laboratorium

Kesahatan Pengujian dan Kalibrasi Provinsi NTB

**Berdasarkan Peraturan Menteri Kesehatan

Nomor 492/Menkes/Per/IV/2010 Tanggal 19

April 2010[7]

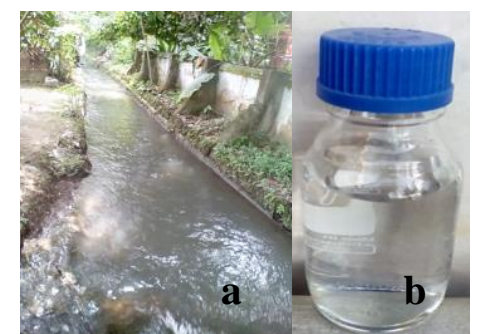

Gambar 2. (a) air sebelum (b) air setelah pengolahan

Para pengguna air diminta untuk mengisi kuisoner tentang kualitas air, harga air dan kebersihan tempat pengolahan air dan karyawan. Responden yang terkumpul adalah 22 orang dengan karakteristik seperti pada Gambar 3. Koresponden terdiri dari laki-laki dan perempuan dengan tingkat pendidikan beragam mulai lulus Sekolah Dasar hingga Perguruan Tinggi dan usia 15 tahun hingga 70 tahun.

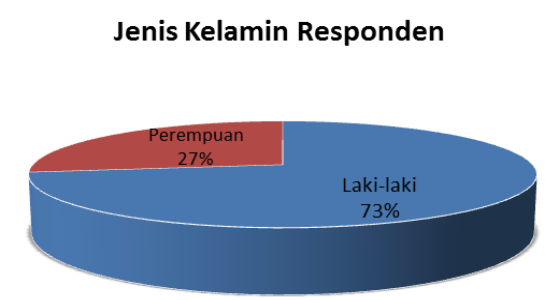

Tingkat Pendidikan Responden

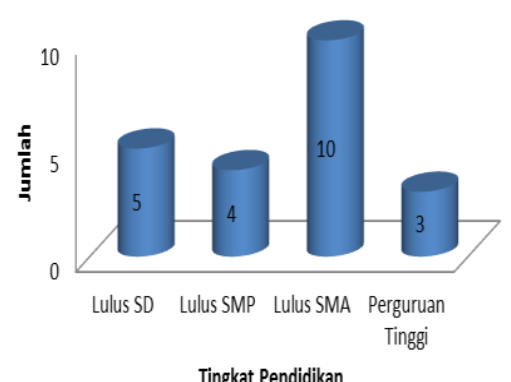

Usia Responden

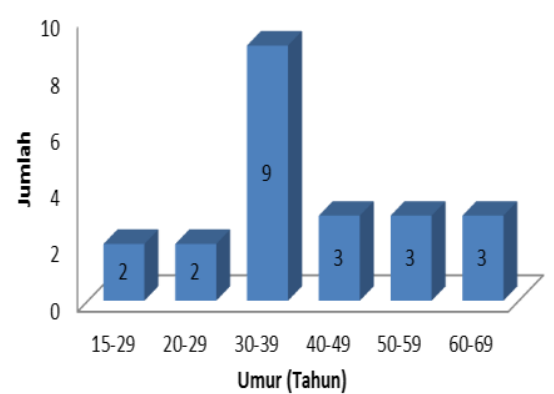

Gambar 3. Karakteristik Responden

Tanggapan Responen terhadap kualitas air, harga dan kebersihan tempat pengolahan dan karyawan disajikan pada Gambar 4 berikut. Tanggapan responden diwakili dengan pemberian skor 1, 2, 3, 4 dan 5. Secara umum koresponden menilai bahwa kualitas air sangat baik dengan harga yang terjangkau dan kebersihan tempat pengolahan dan karyawan baik.

Masyarakat merespon positif terhadap alih teknologi ini karena dapat memenuhi kebutuhan air minum mereka dengan harga yang terjangkau. Pembangunan sentra pengelolaan air siap minum diharapkan menjadi edukasi bagi masyarakat mengenai perilaku hidup bersih dan sehat. 


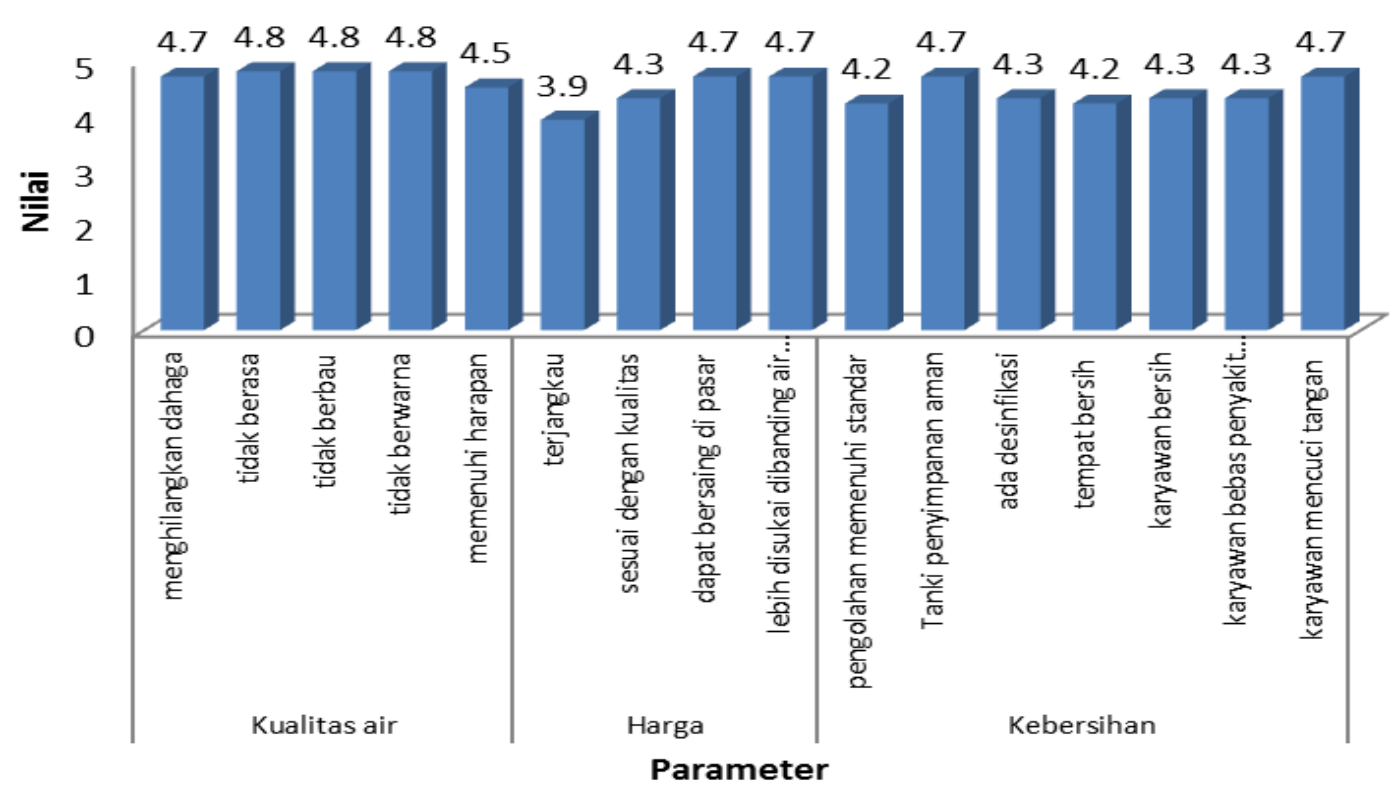

Gambar 4. Tanggapan Responden terhadap kualitas, harga dan kebersihan tempat pengolahan dan karyawan.

\section{KESIMPULAN}

Telah dibuat alat pengolahan air siap minum dengan menggunakan gabungan teknik filtrasi, adsorpsi, RO dan desinfikasi lampu UV. Air hasil pengolahan memiliki karakteristik fisik, kimia dan biologi yang layak untuk air minum. Uji organoleptik menunjukkan bahwa masyarakat menyukai air hasil pengolahan dan merespon positif terhadap alih teknologi pengolahan air.

\section{UCAPAN TERIMA KASIH}

Ucapan terimakasih disampaikan kepada pihak DP2M KEMENRISTEK-DIKTI yang telah memberikan dana kegiatan pengabdian kepada masyarakat pada tahun 2017 melalui skim Ipteks bagi Masyarakat (IbM). Ucapan yang sama disampaikan kepada kelompok tani Patuh Angen Desa Jago dan P3A Desa Jago Kab. Lombok Tengah sebagai mitra kegiatan.

\section{DAFTAR PUSTAKA}

[1] Badan Pusat Statistik Kabupaten Lombok Tengah, 2015, Statistik Daerah Praya 2015, diakses dari http://lomboktengahkab.go.id pada Tanggal 25 Mei 2016.

[2] Myers, B., Williams, E., and Hobgen, S. 2016. Irrigation Water Everywhere - But Is It Fit to Drink?. Prakarsa. Issue 23, January 2016.

[3] KPMLH Kabupaten Lombok Tengah, 2003. Data Base Kualitas Lingkungan Hidup Kabupaten Lombok Tengah, Praya.
[4] Badan Pusat Statistik Provini Nusa Tenggara Barat, 2015, Nusa Tenggara Barat dalam Angka 2015, diakses dari http://ntb.go.id pada Tanggal 25 Mei 2016.

[5] Asmadi, 2015, Akselerasi Peningkatan Mutu Proses Pendidikan di Nusa Tenggara Barat Berbasis Budaya Lokal Menuju Masyarakat Literasi, Prosiding Seminar Nasional Pendidikan Bahasa Indonesia 2015 ISSN: 2477-636X.

[6] Ismillayli, N., Mardiana, L., Kurnianingsih, R., Hermanto, D., \& Fahrurazi, F. (2017). Teknologi Pengelolaan Air Siap Minum Di Desa Jago Kabupaten Lombok Tengah. Jurnal PIJAR MIPA, 12(2). 102-106, DOI: 10.29303/jpm.v12i2.349.

[7] Nomor, P. M. K. R. I. (2016). 492. MENKES/PER/IV/2010 tentang Persyaratan Kualitas Air Minum. http://jdih.pom.go.id/showpdf.php, Persyaratan Kualitas air Minum-JDIH, diakses pada tanggal 25 Mei 2016. 